\title{
OVERVIEW OF ASEAN ENVIRONMENT, TRANSBOUNDARY HAZE POLLUTION AGREEMENT AND PUBLIC HEALTH
}

\author{
Nazia Nazeer ${ }^{*}$ \\ Faculty of Economics and Administration, University of Malaya, \\ Jalan Pantai Baharu, 50603 Kuala Lumpur, Malaysia \\ email: nazia.fea@gmail.com \\ Fumitaka Furuoka ${ }^{* *}$ \\ Asia-Europe Institute, University of Malaya, \\ Jalan Pantai Baharu, 50603 Kuala Lumpur, Malaysia \\ E-mail: fumitakamy@gmail.com
}

Published online: 15 January 2017

To cite this article: Nazeer, N. and Furuoka, F. 2017. Overview of ASEAN environment, transboundary haze pollution agreement and public health. International Journal of Asia Pacific Studies 13 (1): 73-94, http://dx.doi.org/10.21315/ijaps2017.13.1.4

To link to this article: http://dx.doi.org/10.21315/ijaps2017.13.1.4

\begin{abstract}
The hazardous consequences of haze and fires compelled the ten fellow countries of ASEAN to conclude a historic regional agreement on transboundary haze pollution to confront this problem. This paper provides an overview of ASEAN environmental conditions, the failure of the Transboundary Haze Pollution Agreement, and the adverse effects of its failure on public health. The study argues that there is a potential in the region to overcome the haze problem; although the ASEAN haze agreement lacks enforceable obligatory provisions, it remains a beneficial vehicle for regional cooperation to eradicate transboundary pollution.
\end{abstract}

Keywords: ASEAN environment, haze pollution, transboundary agreement, public health, regional cooperation 


\section{INTRODUCTION}

The Association of Southeast Asian Nations (ASEAN) comprises ten autonomous nations, namely Malaysia, Brunei, Singapore, the Philippines, Thailand, Vietnam, Indonesia, Myanmar, Cambodia and Laos, situated along the south-eastern shore of Asia. The ASEAN states include almost half a billion individuals spread throughout the region, from economically strong nations such as Singapore to lesser economies such as Laos, Cambodia and Myanmar (International Energy Agency 2013). In recent years, an alarming issue of large-scale land and forest fires has become a severe environmental and public health problem worldwide, particularly in Southeast Asia. The intentional use of fire to clear land and forests, mostly in Indonesia, leads to frequent smoke and pollution periods in the ASEAN region, most severely in 1997-1998. A monitoring system is needed for the prevention of forest and land fires, accompanied by additional preventive methods, outside expertise and assistance and the improvement of firefighting capability, particularly in Indonesia (Tan 2005). These challenges involve a higher level of exterior control applied by state governments inside ASEAN (Asian Development Bank 2001).

\section{Regional Environmental Degradation}

Environmental degradation in Southeast Asia depends upon the region's changing political economy, urbanisation and methods of production. Subsistence living is the basic mode of survival for almost half of the state's population. This type of lifestyle depends heavily upon the utilisation of natural resources and environmental facilities. Nevertheless, the main reason for environment degradation and scarceness of resources in ASEAN is "industrialisation of Asia in the world economy" (Vervoorn 1998: 157). The state's political economy is characterised by extraordinary rates of growing urban populations, with commensurate increases in energy demand and consumption. ASEAN covers approximately 600 million people, or nine percent of the world's population, with Indonesia holding the largest population and Brunei the smallest within ASEAN. Urbanisation in the Asia-Pacific countries increased from 49 percent in 2005 to 51 percent in 2011 (United Nations 2012).

In the Southeast Asia sub-region, the population increased at an average annual rate of 1.3 percent. However, proportions diverge significantly from nation to nation, with Thailand's growth rate at only 0.5 percent compared with Singapore's 2.5 percent rate - the latter largely a result of immigration. The region's normal population densities of 133 
persons per kilometre square also cover substantial intra- and inter-country dissimilarities. In fact, population densities in the two megacities, that is, Jakarta and Manila, are greater, approximately 10,000 people per kilometre square, than those of Mumbai and Delhi (United Nations Human Settlements Programme 2015). Rapid economic development, low native population and reduced labour force development due to fertility declines encouraged countries such as Singapore to open its doors wide to immigrants from different countries for almost all levels of employment, with the opportunity for stable settlement. Indonesia, the Philippines, and Vietnam are main workforce-exporters, whereas Thailand and Malaysia both accept immigrants and send residents abroad. However, since the 1980s, destinations inside Asia have replaced workforce migration to economies such as the Middle East and the United States. There is noteworthy illegal movement of people in the region. These clusters are predominantly exposed because migrants face health hazards because of insufficient working circumstances but are unlikely to pursue medical care (United Nations Human Settlements Programme 2012/2013). It is estimated that in 2010, the Asia-Pacific region absorbed 53 million worldwide migrants. The proportion of immigrants in the region was almost 1.3 percent, which is equal to 25 percent of the world's overall migrant population in 2010 (United Nations 2012).

The poor in both rural and urban areas are more impoverished and deprived due to environmental, resource and pollution depletion. Industrial manufacture and export-led growth in the area rely on the use of natural resources, renewable forest sources and non-renewable reserves. The increased use of resources for industrialisation changes the approach to production. The "old habit of living within limits" (Clad and Siy 1996) has been damaged by a bias against the so-called "primitive" but more sustainable forms of agriculture (Fox et al. 2000: 15). Transferring cultivation has been discouraged in favour of commercialised, permanent and more intense agriculture. "Pre-existing systems of rights on land, forest, and coastal sources" (Lebel et al. 2004) are disregarded in favour of individual property rights. Customary rights to access resources openly, for instance fuel wood and water in rural areas are badly secured and defined.

Moreover, in a few ASEAN countries, there is proof of military involvement in destructive environment practices, including illegal logging, discarding of risky wastes, species smuggling and fishing. The region has converted to "dirtier, less ecologically diverse and more environmentally vulnerable" practices (Asian Development Bank 1997: 199). Resources have been consumed and the atmosphere polluted to the point that renewable and non-renewable resources and environmental services such as 
clean water and fresh air are being depleted. The percentage of resources exhausted, the drop in environmental services (demand for water and energy), waste production and pollution are at a peak. Consumption of energy in the region has doubled after every 12 years (International Institute for Applied System Analysis 1998). Typhoons, monsoons, the La Nina and El Nino also intensified the overall variation in the wet and hot climate, leading towards floods and droughts in Southeast Asia, particularly Vietnam and the Philippines, which typically are the regions most affected by typhoons. Almost 90 percent of the world's earthquakes occur in Indonesia and the Philippines, which are on the Pacific Ring of Fire. For instance, an earthquake in the Indian Ocean off the shore of Sumatra in 2004 resulted in a devastating tsunami in Aceh, the worst natural calamity on record (Marlier et al. 2013).

Unrestrained fires in the forests of Indonesia in 1997, which were also linked to El Nino, were associated with severe drought (Kurniawan 2002). These fires in Indonesia damaged almost 10 million hectares of forest and grasslands, affecting approximately 300 million people throughout the ASEAN states (Abberger 2003). ASEAN has been identified as a region that might be exposed to effects of environmental changes on public health because there is a large rainfall variability connected to the La Nina and El Nino oscillation.

\section{ASEAN AGREEMENT ON TRANSBOUNDARY HAZE POLLUTION}

On June10 2002, in Kuala Lumpur, Malaysia, ASEAN member nations signed the ASEAN Agreement on Transboundary Haze Pollution. This Agreement was the first regional proposal in the world that aimed to mitigate and prevent haze pollution through concentrated nationwide efforts and increased regional and worldwide cooperation. Unfortunately, two dilemmas lower the efficiency of the agreement. First, Indonesia, the main emitter, has yet to approve this agreement. The second issue is the weak mechanisms for the settlement of disputes and punishing non-compliance (Chareonwongsak 2014). Moreover, the agreement lacks measurable obligations and implementations. Coordination impairment amongst government organisations and the 2001 Indonesia Forestry Law fail to confer the maximum penalties and criminal punishments for illegitimate forest burning, encouraging amendment of the regulations (Tan 2005). The ASEAN Haze Agreement is a mutual cooperative partnership; being neighbours of Indonesia, Malaysia and Singapore might force her to enforce 
domestic improvements with respect to smoke and fire management needs. Moreover, ASEAN's nonaggressive approach and policy of non-interference in member countries' domestic matters constrain Indonesia to implement the intense reforms that might successfully discontinue fires that produce the most transboundary pollution (Cotton 1999; Tan 2005). None of the agreement's obligatory provisions specify any legitimate sanctions for noncompliance; nor is ASEAN constituted as an operative enforcement organisation. ASEAN highlights technical collaboration that might in fact divert attention from strategies that could resolve basic causes of fires and transboundary pollution (Tan 2005). To date, ASEAN representatives have claimed that the Haze Agreement's co-operative procedures deliver the region's most efficient channel to maintain both diplomatic pressure and technical assistance (Kamal 2001; Singh 2008). In fact, the representatives mention that dialogues on the Haze Agreement were among the first times that ASEAN addressed serious differences amongst its participants (Singh 2008).

In 1997, Indonesia was overcome by the financial crisis in Asia and political disorder. Since that period, the transboundary haze and fires have persisted, becoming a yearly occurrence that upsets Singapore, Malaysia and Brunei, with serious incidents occurring in 1999, 2002, 2004, 2006 and 2010. In summary, the issue is recurring, and no sign of a permanent solution is in sight. During the June 2013 haze period, satellite pictures of burning land in Indonesia, mostly in the jurisdiction of Riau on the island of Sumatra, showed that the fires were occurring within large agro-commercial plantations. ${ }^{1}$ However, the agro-commercial community strongly denied responsibility for these fires, placing the blame on small-scale local communities and farmers residing near or within their plantation territories (Tan 2015).

Hence, if ASEAN desires to be instrumental in resolving the haze pollution, it should reassess how to apply the principle of non-intrusion to this specific framework before this haze issue becomes aggravated in the near future (Nelly 2014). The following are the few hindrances in the implementation of the agreement.

\section{Institutional Capacity}

The main obstruction was and continues to be the insufficient standards of administration and governance at both the local and national levels in Indonesia herself. Even in 2002-2003, the forest fires demonstrated fiascos on the part of district and provincial authorities, including government organisations. In fact, 23 laws were approved late in 1985 to address forest 
protection. Unfortunately, the rules and laws are badly managed and enforced; therefore, the burning traditions continue. The inadequate application of the laws and rules is due to the lack of institutional ability (clear objectives, responsibilities, planning, and forest management workforce funding information) to address the issue of forest fires.

\section{Workforce Limitations}

One more constraint on institutional ability at the local and national levels is the absence of a sufficient number of workers engaged in fire-related forest protection and management, which limits the translation of domestic policies into operative programmes. The local courts in Indonesia also lack the awareness of related regulations and laws required to prosecute those involved in starting fires.

\section{Lack of Effective Restriction}

Enforcement of new Indonesian laws limiting environmental exploitation remains tremendously weak. Legal evidence shows only faults of the managers rather than of entire corporations (Maulidia 2006). After the incidence of burning in Indonesia in 1997/1998, 176 plantation and logging companies and transmigration area originators were scrutinised by government for illegal burning, but because of corruption, no-one was sentenced. Low level and less well-paid officers, including officers in the judicial system, can be easily bribed by rich plantation corporations for offences they commit. Whatever developments been formulated in the structural administration of government, corruption remains common and hampers efforts to limit forest burning and land conversion and to accuse those who break the law.

\section{Why the Transboundary Haze Pollution Agreement has thus far failed}

The question is why has there not been a further intense and resilient reaction from Southeast Asian nations, understanding the shocking economic damage the haze has already caused and will continue to cause. The haze issue in Southeast Asia is compelling ASEAN towards exploring approaches to escalate the organisation's political will. ASEAN is also considering how to address complex conditions in which there is poor compliance, corruption, and insubstantial implementation. The haze problem in Southeast Asia is to some extent controllable because it is 
created by humans. Therefore, the Convention on Long-Range Transboundary Air Pollution in Europe stands as a worthy model for how solutions transboundary ecological problems can be effectively undertaken. ${ }^{2}$ The one and only significant reason why ASEAN might not emulate that achievement is that decisions with ASEAN are made only through consensus. As a result, after 12 years, the Agreement on Transboundary Haze Pollution has not thus far been ratified, and Indonesia has not signed the document despite enormous damages to herself in addition to other states. However, it is estimated that the cost to control Indonesian forest fires is approximately USD1.2 billion, which might push towards ecological friendly ways to clean land and encourage Indonesia in efforts towards fire detection and better monitoring. It would be unfair for only Indonesia to absorb the price without assistance from the richest members such as Malaysia and Singapore, enduring not only the cost but also the bulk of the problem (Lassa 2013). Similarly, the two non-polluting countries Malaysia and Singapore would be more than content to abandon the agreement if the sum they pay to control the haze is greater than the damage it causes (Sembiring 2015). A solution for the dispute concerning the source of the money is coming; ASEAN should either alter its policies on consensus and pressure Indonesia to ratify the agreement, or adopt plan B. Plan B was developed by Singapore during the ASEAN meeting held in November 2013. This plan emphasises organising information such as hot spot coordination, satellite data, and enterprise ownership. Unfortunately, the Malaysia and Indonesia governments were not able to share information on maps because of legal restraints. However, the government of Singapore has shown concern by advancing the Transboundary Haze Pollution Bill on 7 July to keep businesses answerable for their activities that cause haze in Singapore (Bay 2014).

Indonesian forest fires are generally considered the major factor in the fire outbreaks that cause the haze in the Southeast Asia region. Indonesia's size and geography as the largest archipelagic state together with the absence of infrastructure lead to interruptions in governmental response time to fires (Jerger 2014).

However, in 2002, the Environment Ministry of Indonesia finalised the initial measures for parliamentary ratification of the Agreement on Transboundary Haze P and made a suggestion to the Agriculture Ministry and the Ministry of Foreign Affairs (Kurniawan 2002). The ministry of Environment pushed for the urgent ratification of the Agreement, mentioning that these measures will contain no sanctions and will have particularly constructive results for the nation (Sijabat 2007). In the same year, Indonesia's House of Representatives and the Environment Ministry 
decided to expedite provisions for ratification of the Agreement on Transboundary Haze Pollution by the middle of 2003. However, this ratification did not occur; thus, President Susilo Bambang Yudhoyono, together with the Ministry of Forestry, acknowledged the agreement as an important bill to be approved in 2004 (Nguitragool 2011).

Nevertheless, the bill was kept under wraps through 2005 (Sijabat 2006). The following year, the State Secretariat finally admitted the Agreement on Transboundary Haze Pollution bill for consideration amongst 78 other bills the Indonesian parliament would debate (Sijabat 2006). However, the parliament again withdrew the bill from the programme with no details (Maulidia 2006). In 2007, a functioning group of 40 officials from agriculture and forestry affairs, defence and foreign affairs, and environmental affairs gave opinions on the Agreement on Transboundary Haze Pollution, which again were insufficient to ratify the agreement (Sijabat 2007). One year earlier, the Indonesian House of Representatives had focussed on ratifying the ASEAN Haze Agreement during their tenure but did not achieve this goal (Parliament of Singapore 2009).

In addition to the influential role of the forestry ministry, one cannot ignore the lobby group activities that had a significant involvement in hindering ratification in the Indonesian parliament. These lobby groups work together in a group, focussing on personal advantages for specific participants (Kurer 1996). The clusters frequently lobby the parliamentarians for their individual benefits (Enderwick 2005) and blockade agreements and policies that might run counter to their interests (Hamilton-Hart 2007). The main players in this lobby group are the Indonesian Palm Oil Association and the Indonesian Sustainable Palm Oil Commission (GAPKI, or Gabungan Pengusaha Kelapa Sawit Indonesia). These groups dominate recommendations and changes in rules and regulations in favour of industry interests. The groups not only have strong lobbies for "the protection of their heritage and lifestyle," which refers to utilisation of peat lands and fire operations in clearing lands for plantation, but also encourage parliamentarians to avoid ratifying the Agreement on Transboundary Haze Pollution. The groups are well aware that, after ratifying the agreement and gaining outside support, the member countries would then pressure the Indonesian Government to proceed with thoughtful measures to solve this haze problem. In addition, the agreement permits an extra protocol that can contain execution and obligation clauses linked to use of fire and peat lands, which would threaten the sector's activities. Legislators also discussed Indonesia not taking advantage of the Agreement and the advantage that the Agreement would give to other ASEAN members (Parliament of Singapore 2010; Budianto 2008; Maulidia 2006). Indonesia 
must make changes in its rules by including a section on zero and illegal scorching activities on peat land (Budianto 2008). In fact, the Indonesian people living in Sumatra and Kalimantan adjacent to the fires would gain maximum benefit from the agreement and the resulting uncontaminated air (Parliament of Singapore 2010). Undoubtedly, the parliamentarians had in mind the economic welfare and activities of the palm oil plantation zone, which was at risk because of the Agreement on Transboundary Haze Pollution, instead of the societal well-being of the nation (Sijabat 2007).

Nevertheless, a few sub-regional fire-fighting operations have been set up in the Sumatra-Riau area and on Borneo. A research and training centre on preventing peat and forest fires was founded at the University of Palangkaraya in Central Kalimantan through the collaboration of NGOs, international bodies, governments, the United Nations Environmental Programme, the Asian Development Bank and the ASEAN Secretariat in handling and helpful roles. With the help of the Asian Development Bank, a division was created at the ASEAN Secretariat to handle external assistance and ASEAN cooperation for the haze and fire problem. Indonesian officials and participants in the Haze Technical Task Force plus the ASEAN Secretariat have met forest concessionaires and plantation property owners to convey to them the zero-burning policy.

\section{The current haze problems created by Indonesian oil palm industries in Riau and Kalimantan}

Maintaining its status as the world's major producer and exporter of palm oil (McCarthy 2010; Jarvis et al. 2010; World Growth 2011), the activities of plantation enterprises in Indonesia are supposed to be justifiable, viable actions not forbidden by international law. However, an obligation would arise on Indonesia's side to reduce the hazard of substantial transboundary harm (Tan 1999).

A dominant feature of the Indonesian palm oil industry is a prominence of investment linkages (Varkkey 2012, 2013), particularly based on sufficient knowledge and contacts in domestic markets, networks with bureaucracy, business structures, financing and prospective business associates (Terjesen and Elam 2009). Hence, it is common amongst the highest-ranking Indonesian plantation industries to have "functional directors" and "advisors" do "extra-economic functions" (Gomez 2009). Patron-client relationships, which are widespread inside the sector (Aggarwal and Chow 2010), support numerous direct relationships of politicians in office to these plantation benefits. This condition promotes elites to support measures that safeguard regional and domestic political 
economic stability and market access to these natural resources (Solingen 1999). Approximately 43 million Indonesians had been constantly exposed to toxic haze smoke in Sumatra and Kalimantan (Campbell 2014). In spite of these actions, haze contamination has continued every year since1997 due to the burning on peat lands in Kalimantan and Sumatra. In 2015, the fires scorched approximately two million hectares of land. Although El Nino is no longer considered a controlling factor, the consistency of the haze problem is due to oil palm extension into peat areas. The largescale growth of peat has occurred because of less inherent land-right claimants (Antara News 2015).

Large firms are considered the lawbreakers behind the land-clearing fires, directly or indirectly. Earlier, analysts assigned 80 percent of the fire responsibility to the business actors and only 20 percent to farmers. In October 2015, in the middle of the haze crisis, unexpected and abrupt shifts in Indonesian authority and policy towards eco-sustainable palm oil were observed. The controlling Indonesia Sustainable Palm Oil (unit under the Ministry of Agriculture and co-funded by the United Nations Development Programme [UNDP]) had a shocking adjustment in governance. The main business-headed Indonesia Palm Oil Pledge (IPOP) was ordered to offset their work, as the administration was seemingly concern for smallholder development and market contact with preventive sustainable policies and corporate inductees. Malaysia and Indonesia have also come to palm oil joint-marketing meetings. Many new studies and reviews have revealed that small, autonomous cultivators, who have been violating the regulations on peat lands in Sumatra and Kalimantan provinces, are the major source of haze pollution. A study by the United Nations suggested that farmers who landed in Kalimantan were actually settled by Indonesia's Transmigration Program of the 1960s and 1970s. Furthermore, these farmers could be responsible for peat fires because they continuously use fire when growing rice paddies, fruits, vegetables, palm oil and rubber. Environmental science studies provide a clear picture showing that 59 percent of the fires originate from timber and palm oil franchise boundaries in Sumatra. However, in Kalimantan, fires have an even greater part; outside businesses generate almost 73 percent of overall emissions and approximately 76 percent of the smoke. The Global Forest Watch website (1 July to 2 November 2015) indicates that nearly 26 percent of the fires were on palm oil plantation parts, whereas two percent were on pulpwood concessions, and approximately 103 of 3,215 fires were on RSPO certified land.

Albeit Agreement on Transboundary Haze Pollution ratification might possibly be sensible at the local level, to Indonesian business and political leaders, it is not logical. This perception builds resistance towards 
ratification in Indonesia at the parliamentary and ministry levels. The agriculture industry, which is one of the main sectors of the Indonesian economy, is largely responsible for Indonesia's fires, which trigger haze. Indonesia may have an ideal cultivating environment for palm trees (a major crop), which produces palm oil and has most of the valuable tropical timber. Almost 60 percent of Indonesia consists of forestland, and 22 million hectares are peat lands. Unfortunately, in the last few years, these peat lands have been used up to make forest and palm oil plantations. These consumed peat lands catch fire more easily and can last with underground burning even when extinguished on the surface. Although a few fires occur because of "lightning strikes on parched, peat-rich lands," there is extensive evidence that the majority of Indonesia's fires are the outcome of the slashand-burn agriculture engaged in by the logging industries and palm oil plantations (National Development Planning Agency [BAPPENAS] 2009).

The traditional practice of slash and burn agriculture for clearing land in South Asia relies on fire to clear the land for plantation because it is easy, cheap and effective, particularly in Indonesia. However, the haphazard use of this traditional technique damages the vegetation that shields peat lands, leaving them vulnerable and exposed to fire. The timber and plantation industry have been capable of executing slash-and-burn agriculture on such a large scale partly because they have remained effective in inducing Indonesian forest and land-use policies to maximise their personal shortterm advantage. In 1995, the government of Indonesia banned using fire to clear land, but the ban has not been enforced successfully due to Indonesia's relative poverty and the fact that slash-and-burn agriculture is an old-style land-clearing method supposed to create more-fertile land. Hence, haze is the end result of Indonesian fires. The haze moves across borders, making it an international issue (Page et al. 2009).

Moreover, there is a scarcity of collaboration amongst Indonesia's national organizations (Nesadurai 2008, Nguitragool 2011). For instance, the Ministries of Agriculture and Forestry are the more influential ministries, with a superior workforce, mandate, and budgetary means (Tan 2004). Although the Ministry of Environment is the backbone of Indonesia's ecological diplomacy and grasps the mandate to negotiate ecological agreements on behalf of Indonesia, the executives manipulate decisionmaking consultants on forest and land policy at the official level (Nguitragool 2011). This manipulation aggravates Indonesia's main concern, in which the value of the natural resources (land and forests) is considered more critical than protection of the environment (Elliott 2003). Similarly, the Forestry Ministry is considered highly responsible for the misuse of business licensing of the forest to private firms, although the 
Environment Ministry retains a simple role for synchronizing and administrative purposes (Tan 2004). Hence, the Agriculture and Forestry Ministries have closer contacts with plantation firms than does the Ministry of Environment. Consequently, in ASEAN meetings related to haze, the representative from the Ministry of the Environment has largely been powerless to stimulate decision-making (Nguitragool 2011).

\subsection{Health effects}

The effect of the environment on human wellbeing had been witnessed since Hippocrates in $400 \mathrm{BC}$, where in his book Air, Water and Places he highlighted the significance of environmental situations such as atmospheric variables on general human health and disease. Inconsistent air pollution incidents, such as the historic London haze/fog in 1952 and a number of epidemiological analyses indicated the effects of air quality inversions on human wellbeing. A persistent conclusion is that air impurities are the main source of increased hospital admissions and mortality (Brunekreef and Holgate 2002). Public health effects include nausea, birth deficiencies, breathing problems, severe growth delays in children, skin allergies, cancer, and respiratory tract diseases. However, the function of numerous other body organs can also be affected (Cohen et al. 2005; Huang and Ghio 2006; Sharma and Agarwal 2005).

It is estimated that health-connected costs of the haze were approximately USD 164 million. A rise in particulate matter with diameter $10 \mu \mathrm{m}$ or less from $50 \mu \mathrm{g} / \mathrm{m} 3$ to $150 \mu \mathrm{g} / \mathrm{m} 3$ was related to increases of 12 percent in upper respiratory tract diseases, 19 percent in asthma and 26 percent in rhinitis in Singapore. In Malaysia, fire-connected diseases such as chronic obstructive pulmonary disease and asthma increased significantly. Research showed that people above 65 years of age suffered more from cardio respiratory diseases during the haze period in 1997. In addition to respiratory diseases, environmental deterioration, largely consisting of rises in rainfall and temperature, spread infectious illnesses such as vector-borne diseases in the ASEAN region. 


\subsection{Effects of air toxins on human health}

\subsubsection{Respiratory system}

Several studies explain that all forms of air toxic waste can affect the air route in humans. Indications such as throat and nose irritation followed by dyspnoea and bronchoconstriction, particularly among asthma patients, are typically suffered after contact with a high rate of nitrogen oxides (Kagawa 1985), sulphur dioxide (Balmes et al. 1987), and several substantial metals such as nickel or vanadium and arsenic. Additionally, particulate matter that penetrates the alveolar epithelium (Ghio and Huang 2004) and ozone start lung infections (Uysal and Schapira 2003). These pollutants will aggravate the health condition of patients suffering from lung illnesses. Moreover, excess nitrogen oxides in air increase sensitivity towards respiratory infections (Chauhan et al. 1998). Finally, contact with ozone together with certain heavy metals lessens the efficiency of lungs (Rastogi et al. 1991; Sharma et al. 2005); the former also causes emphysema, asthma, and lung cancer (Kuo et al. 2006; Nawrot et al. 2006).

\subsubsection{Cardiovascular system}

Excessive carbon monoxide in air combines with haemoglobin to reduce the capability to transmit oxygen in the human body (Badman and Jaffe 1996). This decreased availability of oxygen can affect the working of various organs that depend upon a high oxygen concentration, specifically, the heart and brain, causing blood clotting (Riediker et al. 2004). Air pollution, which aggravates lung inflammation and blood clotting, can block heart blood vessels, leading to myocardial infarction or even angina (Goering 1993).

\subsubsection{Nervous system}

The nervous system is particularly affected by dense metals, which cause memory disturbances, anger, sleep disorders, fatigue, blurred vision, hand tremors, slurred speech, brain cancer and impaired mental development in children (Kampa and Castanas 2008).

\subsubsection{Digestive and urinary system}

Heavy metals can cause kidney impairment and increase the danger of stone formation and renal cancer (Boffetta et al. 1993; Vamvakas et al. 1993). 
Dioxins and metals affect liver cells (Kimbrough et al. 1977), along with causing liver and gastrointestinal cancer (Mandal 2005).

\subsection{Exposure during pregnancy}

Maternal exposure to air impurities raises risks related to foetal growth and abortion, including low birth weight and preterm delivery. Similarly, dioxins have been found to be transported from the mother to the foetus through the placenta, affecting the growth and development of the central nervous system of newborns (Kampa and Castanas 2008).

\subsection{Natural safeguard}

Individuals living in metropolitan cities are more likely to see atmospheric pollution, caused by industrialisation, high energy demand and transportation. Occupational contact is also a vital issue that must be considered. In addition, measures must be increased by considering appropriate actions to diminish the chance of human pollutant contact.

Political, economic and social growth in recent years has enabled considerable health improvements in certain countries, and lesser changes in others. The geology of the ASEAN region makes it extremely vulnerable to tremors that sometimes result in tsunamis, to periodic floods and typhoons, which increase health threats to the population from natural calamities, and to the effects of climate change. Public strategy in member states should consider these risks pertaining to health, which might have significant economic and social effects. Moreover, all nations in the region are confronted with many chronic diseases. A highly strengthened regional cooperation health policy to share awareness and justify health system processes parallels an urgent need to achieve remarkable health improvements.

There are several challenges to the continuation of the ASEAN plans and initiatives to take on the mission of reducing forest and land fires and their harmful effects. However, from a perspective of on-going ecological reform in Indonesia, Singapore and Malaysia, the Agreement on Transboundary Haze Pollution still has great potential to prove that regional collaboration can facilitate combined resolutions to pressing transboundary ecological problems. Successful outcomes of the agreement can be obtained by thorough protocols that govern how the agreement is to be applied. Several Indonesian oil palm farms have been developed with capital from Singaporean and Malaysian investors (Casson 2000; Wakker 2005). 
However, Malaysian officials join ASEAN-sponsored workshops on prosecuting and investigating illegitimate burning cases (Mayer 2006).

\section{Latest development}

The Agreement on Transboundary Haze Pollution takes note of the "ASEAN minus X" plan for ratification. The Agreement is intended to go into effect with a minimum number of confirmations; not all members are required to ratify the Agreement. This formula was adopted to enable individual member states to go further and faster individually "without upsetting consensus" (Smith 2004). It helps shield member governments from having to commit to joint tasks that they lack the administrative capacity to perform or tasks that they find politically difficult given dominant domestic interests (Nesadurai 2008). Irrespective of the shortcoming of the Agreement on Transboundary Haze Pollution in giving legal implementation for the RHAP, Indonesia continues to consider the agreement a threat to its economic benefits (Florano 2003). As the following debate illustrates, Indonesia's non-ratification of the agreement remained imperative in maintaining access and availability to plantation land in Indonesia, allowing the country to retain its major national economic benefits (Elliott 2003).

On September 16 2014, Indonesia ratified the ASEAN Agreement on Transboundary Haze Pollution, initially signed in 2002. Regional governments can be the answer, but they can also be the source of the problem. Indonesia was the first of the ten signatory states to ratify the agreement; the other members are Malaysia, Brunei Darussalam, Cambodia, Burma, Laos, the Philippines, Thailand, Vietnam and Singapore (Global Legal Monitor 2016). For instance, from 1998 to date, Riau province was governed by three governors who already had been detained for corruption, fraud and exploitation of power in terms of delivering certificates or licences for forest usage and in the tracking down of fire trucks.

In October 2015, the Parliament of Indonesia finally ratified the ASEAN Agreement on Transboundary Haze Pollution under the regime of President Susilo Bambang Yudhoyono. The ratification came with mixed reactions; for some, it is a positive gesture after 12 years of delaying, whereas others consider it a formal acceptance that is merely a blot on a non-enforceable agreement. Moreover, in December of the previous year, Indonesia introduced the much-expected One Map of National Thematic Geospatial Information. However, these efforts or changes cannot be confined to the owned plantations, on which control is uninterrupted; the changes must stretch to raw palm oil fruit purchased on local markets, 
smallholdings possessed by farmers individually for which documentation for sustainably farmed palm oil is non-existent. Changing these approaches will require time, even in the presence of the new transboundary haze regulation and law. Eventually, imposing justice on the real malefactors, rapidly suppressing fires, lessening future incidence of forest fires, and forming the region haze-free zone will be the real metrics of success (Sembiring 2015).

By accepting the contract, Indonesia is forced to collaborate in mounting and applying processes to avert and observe transboundary haze pollution affected by forest or land fires. The agreement also assists Indonesia in replying quickly to requests for information from other member states. However, no legitimate sanction can be enforced on any party that fails to meet its commitments.

Indonesia's ratification might ease the haze dilemma via a combination of global technical collaboration and state legal acts against malefactor companies. The focal corporations are large palm oil manufacturers headquartered in Malaysia and Singapore who possess large plantations in Indonesia. These corporations are responsible for permitting clearing-by-burning agriculture practices in their production out of the country. The Haze Agreement would build up the sharing of technical data under the umbrella of ASEAN cooperation. This approach can improve the accountability of the large players in the region's palm oil business.

\section{CONCLUSION}

Land and forest fire in ASEAN occurs each year and damages countless hectares of forest area, causing haze pollution. Over the years, the number of patients affected by haze also has increased. This study discusses the status of environmental degradation, the failure of the Transboundary Agreement and the resulting severe effect on public health in ASEAN. The study suggest that a few measures should be taken to supress fire, including:

1. Active involvement and cooperation among local communities and the private sector;

2. Public, police, student, and armed forces assistance;

3. Awareness programmes, including universities television, newspapers, radio, and posters; and

4. Fire management training, particularly in Indonesia. Moreover, the reduction of transboundary haze will be subject to a joint effort of legal reform, political will and administrative coordination. Although the ASEAN Haze Agreement lacks enforceable 
mandatory provisions, it remains a strong instrument for regional collaboration to control transboundary pollution.

\section{ACKNOWLEDGEMENT}

This work has been developed within the Project UM.TNC2/IPPP/PPGP/628 (BK036-2014), "The Environment and Economic Development in ASEAN Countries" funded by University of Malaya, Malaysia.

\section{NOTES}

Born and raised in Karachi, Pakistan, Nazia Nazeer studied Public Administration in Karachi University, Pakistan. She is a certified human resource and management specialist. Previously, she worked as a manager for Basil Biopharm, Pakistan. She has worked on many projects involving environment, human resources and management. She provides thought leadership and pursues strategies for engagements with senior executives on business and technology. She has interned with the Pakistan International Airlines and Mitchell's Fruit Farms Limited, receiving recognition in developing organisational structures for different departments. She was also rewarded with certificate of excellence from Department of Neurology on establishing strategies. She provides consultancy in constructing manual for Bait-ulSakoon Hospital, Karachi. Nazia also worked under project Employee Performance Measurement in Quality Management Context and Future Perspective of Human Resources. She organises seminars and training sessions on human resources, communication skills, finance and marketing. She also holds a Diploma in Labour Law. She is currently a PhD student at the Faculty of Economics and Administration, University of Malaya, Malaysia. She has been engaged with ASEAN Environment and Economic Development project. She has also attended several courses in development studies and published articles with special concern on Pakistan technological up-gradation. Additionally, she assists in bridging between Karachi University, Lahore School of Economics, Institute of Business Administration and University of Malaya. She has attended and assisted in organising several seminars and conferences in University of Malaya. She also tutors undergraduate students in University of Malaya. Her research interests include ASEAN environment, technology transfer, technological capabilities and organisational capabilities.

** Fumitaka Furuoka is currently a visiting senior research fellow at Asia-Europe Institute, University of Malaya. Previously, he taught Economics at the School of Business and Economics, Universiti Malaysia Sabah (UMS) from 2003 to 2012. He organises workshops for students and is a key player in coordinating research fellows and academicians. He was a lecturer at the Faculty of Economics and Business, Universiti Malaysia Sarawak (UNIMAS) from 1999 to 2013. Before joining the academia, he was a senior assistant at Consulate-General of Japan, Penang from 1991 to 1999. Furuoka obtained his PhD from School of Social Sciences, Universiti Sains 
Malaysia (USM) in 2002. He is the principal investigator of "The Environment and Economic Development in ASEAN countries" project. He assists in organising seminars in Asia-Europe Institute to bring together the scholars from different regions of the world. He also associates with different departments in University of Malaya and invite speakers from other countries. His research focuses on ASEAN environmental conditions and renewable and non-renewable resources in this region. His interest is on policies that mitigate emission in developing countries particularly in ASEAN. His main interests are Environmental Kuznets curve theory, labour economics, development economics and environmental economics.

1 See "Singapore haze hits record high from Indonesia fires," BBC News (London, 21 June 2013) online: BBC News accessed 23 August 2014; Tan, A. K. J., "Forest fires of Indonesia: State responsibility and international liability," International and Comparative Law Quarterly Vol. 826, No. 3 (1999)

2 This convention, which came into effect in 1983 and involved 51 parties, was designed to cut air pollutant emissions.

\section{REFERENCES}

Abberger, H. 2003. Staff of the Integrated Forest Fire Management Program. Jakarta: Indonesia.

Aggarwal, V. K. and Chow, J. T. 2010. The perils of consensus: How ASEAN's metaregime undermines economic and environmental cooperation. Review of International Political Economy 17 (2): 262-290.

Asian Development Bank. 1997. Emerging Asia: Changes and challenges. Manila: Asian Development Bank. 2001. Fire, smoke and haze: The ASEAN response strategy. Manila: Asian Development Bank.

Badman, D. G. and Jaffe, E. R. 1996. Blood and air pollution: State of knowledge and research needs. Otolaryngol: Head and Neck Surgery 114 (2): 205-208, http://dx.doi.org/ 10.1016/S0194-5998(96)70166-3.

BAPPENAS. 2009. Reducing carbon emissions from Indonesia's peat lands. Interim report of multi-disciplinary study, Indonesian National Development Planning Agency, Government of Indonesia, December.

Balmes, J. R., Fine, J. M. and Sheppard, D. 1987. Symptomatic bronchoconstriction after short-term inhalation of sulfur dioxide. American Review of Respiratory Disease 136 (5): 1117-1121, http://dx.doi.org/10.1164/ajrccm/136.5.1117.

Bay, H. M. 2014. Singapore transboundary haze law: We didn't start the fire. It was always burning. ASEAN Today, 12 August.

Boffetta, P., Merler, E. and Vainio, H. 1993. Carcinogenicity of mercury and mercury compounds. Scandinavian Journal of Work, Environment and Health 19 (1): 1-7.

Brunekreef, B. and Holgate, S. T. 2002. Air pollution and health. The Lancet 360: 1233 1242.

Budianto, L. 2008. Lawmakers refuse to endorse forest haze bill. Jakarta Post, 14 March. 
Campbell, L. A. 2014. Disturbance effects on carbon content and tree species traits in tropical peat swamp forest in Central Kalimantan, Indonesian Borneo. Dalhousie University, Halifax (Canada) http://www.outrop.com/uploads/7/2/4/9/7249041/ lad_campbell_2013_-_bornean_tropical_peat_swamp_forests.Pdf.

Casson, A. 2000. The hesitant boom: Indonesia's oil palm sub-sector in an era of economic crisis and political change. Occasional paper no. 29, Center for International Forestry Research Bogor, Indonesia.

Chareonwongsak, K. 2014. ASEAN's limits in conflict resolution in the region. Presented at the International Security in the Asia-Pacific: Beyond ASEANcentred Security? Nanyang Technological University, 9-10 October.

Chauhan, A. J. et al. 1998. Exposure to nitrogen dioxide (NO2) and respiratory disease risk. Review Environment Health 13 (1-2): 73-90.

Clad, J. and Siy, A. M. 1996. The emergence of ecological issues in Southeast Asia. In Southeast Asia in the New World Order, ed. Wurfel, D. and Burton, B., 52. London: MacMillan.

Cohen, A. J. et al. 2005. The global burden of disease due to outdoor air pollution. Journal Toxicology and Environmental Health 68, 1301.

Cotton, J. 1999. The "haze" over Southeast Asia: Challenging the ASEAN mode of regional engagement. Pacific Affairs 72 (3) 331-351, http://dx.doi.org/ $10.2307 / 2672225$.

Enderwick, P. 2005. What's bad about crony capitalism? Asian Business and Management 4: 117-132.

Elliott, L. 2003. ASEAN and environmental cooperation: Norms, interests and identity. The Pacific Review 16 (1): 29-52.

Florano, E. R. 2003. Assessment of the "strengths" of the New ASEAN agreement on transboundary haze pollution. International Review for Environmental Strategies 4 (1): $127-147$.

Forest and land Fires ravage two million hectares. 2015. Antara News, 31 October.

Fox, E. A. 1993. Report for the National Science Foundation. Blacksburg, VA: Virginia Tech Department of Computer Science.

Fox, J. et al. 2000. Shifting cultivation: A new old paradigm for managing tropical forests. BioScience 50(6): 521-528.

Ghio, A. J. and Huang, Y. C. 2004. Exposure to concentrated ambient particles (CAPs): A review. Inhalation Toxicology 16 (1): 53-59, http://dx.doi.org/10.1080/ 08958370490258390.

Global Legal Monitor. 2016. Indonesia: Regional haze agreement ratified. Washington: Library of Congress.

Gomez, E. T. 2009. The rise and fall of capital: Corporate Malaysia in historical perspective. Journal of Contemporary Asia 39 (3): 345-381.

Goering, P. L. 1993. Lead-protein interactions as a basis for lead toxicity. Journal of Neuro Toxicology 14 (2-3): 45-60.

Hamilton-Hart, N. 2007. Government and private business: Rents, representation and collective action. In Indonesia: Democracy and the promise of good governance, ed. McLeod, R. H. and MacIntyre, A., 93-111. Singapore: Institute of Southeast Asian Studies. 
Huang, Y. C. T. and Ghio, A. J. 2006. Vascular effects of ambient pollutant particles and metals. Current Vascular Pharmacology 4 (3): 199-203.

International Institute for Applied System Analysis (IIASA). 1998. Paper presented at Workshop on Transport of Air Pollution in Asia, 27-29 July, Laxenburg, Australia.

International Energy Agency. 2013. World energy outlook 2013. London: International Energy Agency.

Jarvis, D. et al. 2010. Palm oil in Southeast Asia. Asian Trends Monitoring Bulletin 4: 118.

Jerger, D. B. 2014. Indonesia's role in realizing the goals of ASEAN's agreement on transboundary haze pollution. Sustainable Development Law and Policy 14 (1): $35-45$.

Kagawa, J. 1985. Evaluation of biological significance of nitrogen oxides exposure. Tokai Journal of Experimental and Clinical Medicine 10 (4): 348-353.

Kamal, A. 2001. ASEAN's response strategy in addressing transboundary haze pollution. ASEAN Biodiversity July-September 11-14.

Kampa, M. and Castanas, E. 2008. Human health effects of air pollution. Environmental Pollution Journal 151 (2): 362-367.

Kurer, O. 1996. The political foundations of economic development policies. Journal of Development Studies 32 (5): 645-668.

Kurniawan, M. 2002. Government ignored warning, fires to continue. Jakarta Post, 31 August.

Kimbrough, R. D. et al. 1977. Epidemiology and pathology of a tetrachlorodibenzodioxin poisoning episode. Archives of Environment Health 32: 77-86.

Kuo, C. Y. et al. 2006. Accumulation of chromium and nickel metals in lung tumors from lung cancer patients in Taiwan. Journal of Toxicology Environment and Health 69 (14): 1337-1344.

Lassa, J. A. 2013. Governing the risk of haze and ASEAN diplomacy. Jakarta Post, 28 June.

Lebel, C. et al. 2004. Nobody knows best: Alternative perspectives on forest management and governance in Southeast Asia. International Environment Agreements 4 (2): 111-127, http://dx.doi.org/10.1023/B:INEA.0000040415.96194.b5.

Mandal, P. K. 2005. Dioxin: A review of its environmental effects and its aryl hydrocarbon receptor biology. Journal of Compound Physiology B 175 (4): 221230.

Marlier, M. E. et al. 2013. El Nino and health risks from landscape fire emissions in Southeast Asia. Nature Climate Change 3 (2): 131-136.

Maulidia, M. 2006. Indonesia must ratify anti-haze treaty. Jakarta Post, 14 July.

Mayer, J. 2006. Transboundary perspectives on managing Indonesia's fires. Journal of Environment and Development 15 (2): 202-223.

McCarthy, J. F. 2010. Process of inclusion and adverse incorporation: Oil palm and agrarian change in Sumatra, Indonesia. Journal of Peasant Studies 37 (4): 821850 . 
Nawrot, T. et al. 2006. Environmental exposure to cadmium and risk of cancer: A prospective population-based study. Lancet Oncology 7 (2): 119-126.

Nelly, S. 2014. The 'burning' problem of air pollution in South East Asia. Worldwatch Institute Europe, 1 March.

Nesadurai, H. E. 2008. The Association of Southeast Asian Nations (ASEAN). New Political Economy 13(2), 225-239.

Nguitragool, P. 2011. Negotiating the haze treaty: Rationality and institutions in the negotiations for the ASEAN agreement on Transboundary Haze Pollution. Asian Survey 51 (2): 356-378.

Page, S. et al. 2009. Tropical peatland fires in Southeast Asia. In Tropical fire ecology, ed. Cochrane, M. A., 263-287. Berlin: Springer Berlin Heidelberg.

Parliament of Singapore. 2009. Haze situation: Action plan. Singapore: Parliament of Singapore. . 2010. Haze and forest fires: Commitment from Indonesia. Singapore: Parliament of Singapore.

Rastogi, S. K. et al. 1991. A cross-sectional study of pulmonary function among workers exposed to multi metals in the glass bangle industry. American Journal of Industrial Medicine 20 (3): 391-399, http://dx.doi.org/10.1002/ajim.4700200311.

Riediker, M. et al. 2004. Particulate matter exposure in cars is associated with cardiovascular effects in healthy young men. American Journal of Respiratory and Critical Care Medicine $169 \quad$ (8): 934-940, http://dx.doi.org/10.1164/rccm.200310-1463OC.

Sembiring, M. 2015. Timely for Singapore, Indonesia governments to prove that haze policies work. Straits Times, 10 September, http://www.straitstimes.com/opinion/timely-for-spore-indonesia-govts-to-provethat-haze-policies-work (accessed 10 September 2015)

Sharma, K. and Agarwal. 2005. Biological effects of heavy metals: An overview. Journal of Environmental Biology 26: 301-313.

Sijabat, R. M. (2006). Environment minister warns of haze's serious effects. Jakarta Post, 10 October. . 2007. Government, house discuss bill on transboundary haze. Jakarta Post, 13 March.

Singh, B. 2008. Singapore: Success at home, challenges from abroad. Southeast Asian Affairs 315-330.

Smith, A. L. 2004. ASEAN's ninth summit: Solidifying regional cohesion, advancing external linkages. Contemporary Southeast Asia 26, 416-433.

Solingen, E. 1999. ASEAN, Quo vadis? Domestic coalitions and regional co-operation. Contemporary Southeast Asia 21 (1): 30-53.

Tan, A. K. J. 1999. Forest fires of Indonesia: State responsibility and international liability. International and Comparative Law Quarterly 48: 826-885. . 2004. Environmental laws and institutions in Southeast Asia: A review of recent developments. Singapore Year Book of International Law 8: 177-192. . 2005. The ASEAN Agreement on Transboundary Haze Pollution: Prospects for compliance and effectiveness in post-Suharto Indonesia. New York University Environmental Law Journal 13: 647-722. 
. 2015. The 'HAZE' crisis in Southeast Asia: Assessing Singapore's Transboundary Haze Pollution Act. National University of Singapore working paper 2015/002.

Terjesen, S. and Elam, A. (2009). Transnational entrepreneurs' venture internationalization strategies: A practice theory approach. Entrepreneurship Theory and Practice 33 (5): 1093-1116.

United Nations. 2012. Statistical year book for Asia and the Pacific. Geneva: United Nations.

United Nations Human Settlements Programme. 2012/2013. State of the world's cities. Geneva: United Nations.

2015. The state of Asian and Pacific cities. Geneva: United Nations.

Uysal, N. and Schapira, R. M. 2003. Effects of ozone on lung function and lung diseases. Current Opinion in Pulmonary Medicine 9 (2): 144-150.

Vamvakas, S., Bittner, D. and Koster, U. 1993. Enhanced expression of the proto oncogenes c-myc and c-fos in normal and malignant renal growth. Toxicology Letters 67 (1-3): 161-172.

Varkkey, H. 2012. Patronage politics as a driver of economic regionalisation: The Indonesian oil palm sector and transboundary haze. Asia Pacific Viewpoint 53 (3): 314-329.

. 2013. Patronage politics, plantation fires and transboundary haze. Environmental Hazards 12: 200-217.

. 2014. Regional cooperation, patronage, and the ASEAN Agreement on Transboundary Haze Pollution. International Environmental Agreements: Politics, Law and Economics 14 (1): 65-81.

Vervoorn, A. 1998. Re-orient: Change in Asian societies. Oxford: Oxford University Press.

Wakker, E. 2005. Greasy palms: The social and ecological impacts of large-scale oil palm plantation development in Southeast Asia. London: Friends of the Earth.

World Growth. 2011. The economic benefit of palm oil to Indonesia. Virginia: World Growth. 